\title{
Occurrence of Halogenated Pollutants in Domestic and Occupational Indoor Dust
}

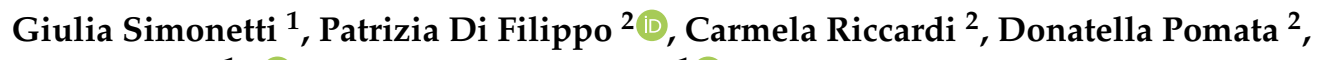 \\ Elisa Sonego ${ }^{1, *(D)}$ and Francesca Buiarelli ${ }^{1}$ (D) \\ 1 Department of Chemistry, Sapienza University of Rome, 00185 Rome, Italy; \\ giulia.simonetti@uniroma1.it (G.S.); francesca.buiarelli@uniroma1.it (F.B.) \\ 2 Dipartimento innovazioni tecnologiche e sicurezza degli impianti, prodotti e insediamenti antropici, \\ Istituto Nazionale per l'Assicurazione contri gli Infortuni sul Lavoro (INAIL), 00143 Rome, Italy; \\ p.difilippo@inail.it (P.D.F.); ca.riccardi@inail.it (C.R.); d.pomata@inail.it (D.P.) \\ * Correspondence: elisa.sonego@uniroma1.it
}

Received: 30 April 2020; Accepted: 24 May 2020; Published: 27 May 2020

\begin{abstract}
The occurrence of halogenated organic pollutants in indoor dust can be high due to the presence of textile, electronic devices, furniture, and building materials treated with these chemicals. In this explorative study, we focused on emerging organic pollutants, such as novel brominated flame retardants (nBFRs) and some perfluoroalkyl substances, together with legacy polychlorinated biphenyls (PCBs) and polybrominated diphenyl ethers (BDEs) in settled dust collected in houses and workplaces such as one office and two electrotechnical and mechanical workshops. The total contribution of the investigated pollutants was lower in house and in office dusts except for few nBFRs (such as bis (2-ethylhexyl)-3,4,5,6-tetrabromo-phthalate at a concentration of $464.5 \mathrm{ng} / \mathrm{g}$ in a house and hexachlorocyclopentadienyldibromocyclooctane at $40.4 \mathrm{ng} / \mathrm{g}$ in the office), whereas in electrotechnical and mechanical workshops a high incidence of PCBs, BDEs, and nBFRs occurred (for example, BDE 209 at a concentration of $2368.0 \mathrm{ng} / \mathrm{g}$ and tetrabromobisphenol A at 32,320.1 ng/g in electrotechnical and mechanical workshops). Estimated daily intakes were also calculated, showing that domestic and occupational environments can lead to a similar contribution in terms of human exposure. The higher exposure contribution was associated to nBFRs, whose EDIs were in the range of 3968.2-555,694.2 pg/kg bw/day. To provide a complete view about the indoor contamination, in this investigation, we also included polycyclic aromatic hydrocarbons (PAHs) and their oxygenated and nitrated derivatives. Definitely, dust collection represents a simple, fast, and cost-effective sampling and dust contamination level can be a useful indicator of environment healthiness. Besides, the presented method can be a smart tool to provide a time and money saving technique to characterize 99 pollutants thanks to a single sample treatment.
\end{abstract}

Keywords: multiclass analysis; halogenated flame retardants; emerging pollutants; indoor settled dust; environmental exposures and health; occupational health; preventive measure

\section{Introduction}

Flame retardants (FRs) are chemicals commonly added to many products to reduce the flammability of that product by increasing the ignition point and curtailing the spread of a fire. However, several studies showed that many of these compounds had adverse health effects, such as endocrine disruption, carcinogenic effects, immunotoxicity, and reproductive toxicity [1]. Among the organic FRs, polychlorinated biphenyls (PCBs), produced since 1930, were used in thousands of consumer products. Some of them, called dioxin-like, have chemical-physical characteristics that make them similar to dioxins and furans, causing therefore the same toxicological effects. European countries 
have started to apply measures to prohibit equipment containing PCBs since 1986, but the complete elimination of PCBs has not been achieved. In addition, brominated flame retardants (BFRs) including polybrominated diphenyl ethers (BDEs) were widely used as additives in industrial materials [2]. The structural similarity of BDEs with thyroxine, the main thyroid hormone, induces interference with the endocrine system [3]. An adverse effect in the neurological development of exposed children has been shown [4] and association between high concentrations of some BDEs in adipose tissues and the onset of cancer was also suggested [5]. Therefore, the Stockholm Convention of 2009 banned production of many of these substances [6,7].

Due to the bans on the use of the aforementioned FRs, but owing to their essential role, new brominated flame retardants (nBFRs) have been introduced on the market. For these alternative chemicals, little or no toxicity data exist; therefore, there is no scientific evidence that these products are safer than the banned ones. Indeed, because of physico-chemical properties similar to the legacy FRs, a similar toxicological behavior would be expected, including the endocrine toxicity, carcinogenicity, and environmental fate [8]. Among the main nBFRs in use, we investigated the chemicals listed in Table 1 and described below.

Table 1. Investigated nBFRs, their abbreviations, restriction and the main applications and uses.

\begin{tabular}{|c|c|c|c|}
\hline Abbreviation & Nomenclature & Restriction & Application and Use \\
\hline TBBPA & Tetrabromobisphenol A & $\checkmark^{*}$ & $\begin{array}{l}\text { Additive in resins used in plastic casings of } \\
\text { electronic devices and in printed circuit } \\
\text { boards and in several types of polymers [9]. }\end{array}$ \\
\hline ТВPH & $\begin{array}{c}\text { bis } \\
\text { (2-ethylhexyl)-3,4,5,6-tetrabromo-phthalate }\end{array}$ & $\mathrm{X}$ & $\begin{array}{l}\text { Used in the foams of polyurethane as a } \\
\text { mixture of TBB and TBPH (ratio about } 4: 1 \\
\text { in mass) commercially known as } \\
\text { "Firemaster 550". }\end{array}$ \\
\hline TBB & 2-Ethylhexyl-2,3,4,5-tetrabrombenzoate & $\mathrm{X}$ & Additive in foams of polyurethane. \\
\hline TBP & 2,4,6-tribromophenol & $x$ & $\begin{array}{l}\text { Added in polyurethanes plastic, resins and } \\
\text { paper-based products and flame retardant } \\
\text { intermediate [10]. }\end{array}$ \\
\hline ВТВРЕ & 1,2-bis(2,4,6-tribromophenoxy) ethane & $\checkmark * *$ & $\begin{array}{l}\text { Additive used in acrylonitrile-butadiene } \\
\text { styrene copolymers (ABS), high impact } \\
\text { polystyrenes (HIPS), and in electronics. }\end{array}$ \\
\hline DPTE & $\begin{array}{l}\text { 2,3-dibromopropyl-2, 4, } \\
\text { 6-tribromophenylether }\end{array}$ & $\checkmark * *$ & $\begin{array}{l}\text { Main component of the brominated flame } \\
\text { retardant (BFR) Bromkal 73-5 PE. }\end{array}$ \\
\hline ATE & Allyl-2,4,6-tribromophenyl ether & $\checkmark * *$ & $\begin{array}{l}\text { Additive use in EPS and PS foam (both } \\
\text { rigid and flexible foams). }\end{array}$ \\
\hline HBB & Hexabromobenzene & $x$ & $\begin{array}{l}\text { Additive flame retardant in paper, textiles, } \\
\text { electronics, and plastics and decomposition } \\
\text { product of other FRs. }\end{array}$ \\
\hline $\mathrm{HCDBCO}$ & Hexachlorocyclopentadienyldibromocyclooctane & $\mathrm{X}$ & $\begin{array}{l}\text { Additive in plastics and polymers, } \\
\text { especially in polystyrene [11]. }\end{array}$ \\
\hline PBBA & Pentabromobenzyl Acrylate & $x$ & $\begin{array}{l}\text { Used as monomer in dispersion } \\
\text { polymerization process polyester } \\
\text { and polystyrene. }\end{array}$ \\
\hline PBEB & 2,3,4,5,6-pentabromoethylbenzene & $\checkmark * *$ & $\begin{array}{l}\text { Additive in circuit boards, textiles, wire } \\
\text { coatings, and polyurethane foam [12]. }\end{array}$ \\
\hline ТВCO & 1,2,5,6-tetrabromocycloctane & $\mathrm{X}$ & $\begin{array}{l}\text { Additive in plastics, paints and in the } \\
\text { textile industry. }\end{array}$ \\
\hline TBECH & $\begin{array}{l}\text { 1,2-dibromo-4-(1,2-dibromoethyl) } \\
\text { cyclohexane }\end{array}$ & $X$ & $\begin{array}{l}\text { Additive in construction materials, electric } \\
\text { cables, polystyrene-based insulation panels, } \\
\text { plastics and adhesives. }\end{array}$ \\
\hline
\end{tabular}

* Legislative restrictions in Europe through the IPPC (Integrated Pollution Prevention and Control) Directive [13].

** Chemicals listed as Low Production Volume (LPV) chemical in Europe.

Often data were insufficient to provide a clear picture of these chemicals; however, some studies were available about toxicity and health effects. TBBPA, the most widely produced brominated flame retardant in the world, was related to effects on reproductive and nervous system development, 
including brain and thyroid function. TBP, the most widely produced brominated phenol, has been described as a disruptor of hormonal regulation [14]. Among tribromophenoxy FRs, BTBPE, DPTE (or TBP-DBPE), and ATE (or TBP-AE), extensively used in the US and China, may exhibit the same toxicity mechanism of BDEs for their structural similarity [15]. Although HBB is not teratogenic or fetotoxic, it is metabolized in rat liver into toxic molecules [16]. PBBA shows the ability to bind and activate estrogen and androgen receptors, but data are insufficient to provide a clear picture [17]. TBCO, used in replacing HBCD (hexabromocyclododecane), shows similar potentials for bioaccumulation, persistence, and long-range atmospheric transport as BDEs and HBCD [18]. In vitro studies about TBECH have shown the ability to bind and activate the androgen receptor (hAR) with high affinity. Even low-level exposure may cause behavioral, functional, and developmental disorders [19].

Perfluorinated alkylated substances (PFAS) represent another emerging pollutant of increasing interest added to many materials to increase their resistance. PFAS have been produced since 1920; in particular, perfluoroctane acid (PFOA) and perfluoroctane sulfonic acid (PFOS) were extensively used; however, many in vivo and in vitro studies have suggested that exposure to PFOS may lead to adverse effects on human health, such as hepatotoxicity, neurotoxicity, reproductive toxicity, immunotoxicity, thyroid disruption, cardiovascular toxicity, pulmonary toxicity, and renal toxicity [20-22]. Hence, PFOS and its salts were classified as persistent organic pollutants (POP) by the Stockholm Convention in 2009; these compounds are still found in the environment, because of their persistence, and because of degradation of molecules alternatively used such as fluorotelomer alcohols (FTOHs) [23].

In this study, we investigated the presence of these pollutants in indoor environments. In fact, electric and electronic components, insulation wires, cables, domestic appliances, furniture, upholstery, mattresses, and carpets can be a source of FRs and PFAS. Then, in indoor environments, such as houses and workplaces, the concentration of these compounds can be high. The settled dust can be rich in FRs both because of the presence in plastic particles abraded from product surfaces, and because of adsorption on dust of volatilized FRs, released from these products. The emission can vary based on product source, kind of released FR, because of the compound-specific release time and rate, determined by its physical properties (FRs with higher vapor pressures evaporate faster even at room temperature) [24]. Hence, a passive deposition onto the surface of the buccal, nasal, and ocular mucous membranes causes indirect ingestion of dust. In addition, dermal adsorption is also an important human exposure pathway. It is noteworthy that the sampling of settled dust is rapid and cost effective compared to air sampling. Despite the difference in dust and air contamination, a simple and rapid chemical characterization of indoor dust, characterized by cost-effective sampling, can be a useful indicator of environmental healthiness. In our previous studies, FRs levels in air and dust of an electrical and electronic waste treatment facility were obtained through an improved analytical method $[25,26]$. In this explorative study, the previous method was optimized and extended to a new pollutant class (PFAS) and to some new BDEs and nBFRs, allowing the monitoring of four different classes of pollutants in domestic and occupational indoor dust. For this purpose, the samples were collected in two houses (apartments), one office, and two electronic and mechanical workshops. In addition, the polycyclic aromatic hydrocarbons (PAHs), their oxygenated derivatives (oxy-PAHs), and nitro-polycyclic aromatic hydrocarbons (nitro-PAHs) were included for their ubiquity and health concern, in perspective of a cumulative exposure assessment to environmental pollutants. Most of the studies have generally focused on a single pollutant class; in contrast, this study, by monitoring a total of 99 compounds, represents an important goal to improve knowledge of human exposure in contaminated indoor environments.

\section{Materials and Methods}

\subsection{Standard}

TBPH, BTBPE, PBBA, all the PCBs, and all the BDEs standards were purchased from Wellington Laboratories (Ontario, Canada); ATE, PBEB, HBB, PFTeDA, FOSA, all PAHs, PAH derivatives and 
mass labeled PCBs, and PFOA, used as internal standards, were purchased from Sigma Aldrich (Milan, Italy); and PFOA, PFOS, PFBS, TBB, TBECH, TBBPA, DPTE, TBCO, and TBP were obtained from AccuStandard Inc. (Connecticut, USA). Stock standard solutions were prepared from solid analytes by dissolving each compound in toluene $(1 \mathrm{mg} / \mathrm{mL})$ or from purchased standard solution $(50 \mu \mathrm{g} / \mathrm{mL})$ sealed with screw-caps and stored at $-20^{\circ} \mathrm{C}$ in amber glass vials.

\subsection{Chemicals, Reagents and Other Materials}

MS grade n-hexane, toluene, ethyl acetate, acetonitrile, methanol, and isopropyl alcohol were purchased from Sigma-Aldrich S.r.l. (Milan, Italy). Water purified by a Milli-Q ${ }^{\circledR}$ Integral system (Merck KGaA, Darmstadr, Germany) (no PFAS containing polymers) was used. Florisil sorbent, 30-60 mesh was purchased from Sigma Aldrich S.r.l. (Milan, Italy). Regenerated cellulose (RC) filters (15 $\mathrm{mm} \times$ $0.22 \mu \mathrm{m}$ ) with polypropylene housing were from Phenomenex (Torrance, CA, USA).

\subsection{Dust Sample Collection}

The dust samples were collected during Summer 2019 in five different sampling sites located in different areas of Rome, namely two domestic environments (D1 and D2), one office (D3), and two electrotechnical and mechanical workshops (D4 and D5), using a household vacuum cleaner in which a single vacuum bag (previously tested for the presence of target contaminants) was fitted for each sampling site for the entire sampling period. During the sampling, no area or time was defined to collect a significant amount of dust. The dust samples were homogenized and sieved ( $63 \mu \mathrm{m}$, Giuliani, Torino, Italy) before use to remove all the impurities (hairs, crumbs etc.) or other non-dust parts; the smaller fraction was finally stored at $-20^{\circ} \mathrm{C}$ until analysis to reduce the possible degradation of the samples.

\subsection{Extraction Procedure and Analysis}

A single sample treatment was optimized for the extraction of all the investigated compounds using accelerated solvent extraction (ASE) technique. In-cell clean-up was used to perform organic pollutant extraction according to other studies [26-28], as well as to perform a simultaneous extraction and purification by ASE. The analyses were carried out using mass spectrometric detectors coupled with high performance liquid chromatography or gas chromatography (HPLC-MS/MS or GC-MS).

An amount of $100 \mathrm{mg}$ of dust spiked with an IS (internal standards) mixture was extracted by an accelerated solvent extractor ASE 200 (Dionex, Sunnyvale, CA, USA). ASE cells were fitted with florisil $(500 \mathrm{mg})$ sorbent to simultaneously obtain extraction and purification of the samples. The extraction was carried out with n-Hexane (one cycle) followed by ethyl acetate (one cycle) and finally isopropyl alcohol/methanol 90/10 (v/v) (one cycle) at $100{ }^{\circ} \mathrm{C}$ and $1500 \mathrm{psi}$. The use of this extraction solvents allowed the extraction of all pollutant classes under investigation from the sample. The extract was split into two equal aliquots and evaporated using an Evaporator SE 500s-Dionex (Dionex, Sunnyvale, CA, USA), quantitatively transferred to conical vials, and carefully evaporated to dryness under a gentle nitrogen stream. Finally, the extracts were re-dissolved with $50 \mu \mathrm{L}$ of toluene for GC-MS analyses and $50 \mu \mathrm{L}$ of acetonitrile for HPLC-MS-MS containing the internal standards. The analyses of 21 PCBs, 11 BDEs, 13 nBFRs, 20 PAHs, and 28 PAH derivatives (oxy-PAHs and nitro-PAHs) were performed in GC-MS. An HP 7890-B gas chromatograph fitted with an HP 7693 autosampler and coupled with an HP 5977B single quadrupole mass-selective detector (Agilent Technologies, Palo Alto, CA) was used for GC-MS analysis both in electronic ionization (EI) and in negative chemical ionization (NCI). The instrument was tuned using the software autotune procedure (Agilent MSD Chem Station D.01.00 software) (Agilent Technologies Italia S.p.A., Cernusco sul Naviglio MI, Italy) and selective ion monitoring (SIM) was used in both MS configurations. The injector temperature was set at $280^{\circ} \mathrm{C}$ and the samples $(1 \mu \mathrm{L})$ were injected in splitless mode. The helium carrier gas was set at a constant flow rate of $1.0 \mathrm{~mL} / \mathrm{min}$. Analytical methods were described in detail in previous studies [25,26,29-31] with the inclusion of PBBA and TBP and implemented with other BDEs. On the other hand, the 
analyses of PFAS, TBBPA, and BDE 209 were carried out using HPLC-MS/MS. The HPLC 1260 Infinity II system (Agilent Technologies Italia S.p.A., Cernusco sul Naviglio MI, Italy), fitted with an autosampler (injection volume $8 \mu \mathrm{L}$ ) Agilent1260 G7129A, was coupled to a triple quadrupole mass spectrometer API 2000 (AB SCIEX S.r.l. Forster City, CA, USA). The apparatus was coupled with an electrospray ionization (ESI) source set at $350^{\circ} \mathrm{C}$, for PFOA, PFOS, PFBS, PFTeDA, FOSA, and TBBPA analysis. The chromatographic separation was carried out with a Gemini $\mathrm{C}_{18} 3 \mu \mathrm{m}, 150 \times 2 \mathrm{~mm}$ (Phenomenex) column. The flow rate was set at $0.2 \mathrm{~mL} / \mathrm{min}$ and the column temperature at $40^{\circ} \mathrm{C}$. The mobile phases A and B were water and methanol, respectively, both containing $5 \mathrm{mM}$ ammonium formate. The following gradient elution was used: $70 \% \mathrm{~B}$ increase to $100 \%$ in $15.00 \mathrm{~min}$, from 15.01 to $29.99 \mathrm{~min}$ keep isocratic, at $30.00 \mathrm{~min}$ return to $70 \% \mathrm{~B}$, and finally re-equilibrate the column at $70 \% \mathrm{~B}$ for $30 \mathrm{~min}$. The injection volume was $5 \mu \mathrm{L}$. The BDE 209 analysis was carried out using the atmospheric pressure chemical ionization source (APCI) in the same chromatographic condition without ammonium formate in mobile phases. The analyses were carried out in negative polarity in multiple reaction monitoring acquisition.

\subsection{Data Quality}

The analytical performances were assessed to verify whether the method fits for the purpose. In absence of a standard reference material, to get the quality assurance, both a procedural blank and a quality control (QC), obtained by spiking to a blank sample a standard mix solution at a LOQ concentration, were processed in each analytical session. Particular attention was paid to verify the absence of contamination given by plastic devices, glassware and solvents and the QC fulfilled the requirements of precision (RSD $\leq 15 \%$ ) and trueness (expressed as relative error, $\mathrm{E} \% \leq 20$ ). The linearity was assessed with $R^{2}$ of standard solvent calibration curves. Instrumental limit of detection (LOD) and quantification (LOQ) were calculated as reported by Buiarelli et al. [25] and described in Section 3.1. The extraction recoveries were calculated with triplicate analyses in two analytical sessions by the ratio of post-extraction versus pre-extraction spiked blank samples. Intra- and inter-day repeatabilities of the method were calculated by replicate analyses of a multistandard solution injected five times in the same day and in five non-consecutive days. Intra- and inter-day repeatability were expressed as (RSD); values within $15 \%$ can be considered suitable for multi-analyte methods.

\subsection{Quantitative Analysis}

Different calibration curves (matrix-free and matrix-matched) were built, both in HPLC-MS/MS and in GC-MS. The standard solvent (matrix-free) calibration curves were prepared using increasing concentrations of analytes and a constant concentration of internal standards (IS). Taking into account the different instrumental sensitivities, in HPLC-MS/MS, concentrations ranged $50.0-1000.0 \mathrm{ng} / \mathrm{mL}$, whereas in GC-MS they ranged $0.5-800.0 \mathrm{ng} / \mathrm{mL}$. The ratio of analyte area to IS area was plotted versus analyte concentration and a linear regression was obtained for each analyte in the linearity range. The quantitative analyses were carried out using the matrix-matched curve, as described by Buiarelli et al. [25]. Briefly, five aliquots of $100 \mathrm{mg}$ of the least contaminated dust in this study (D3) were spiked with IS and pollutant standard solutions at increasing concentrations prior to the extraction. The linear plot of the analyte/IS area ratio versus standard addition concentration was drawn. The analytes concentrations in the office dust were estimated using the intercepts on the abscissa. The other dust samples were quantified using this curve translated to the origin, by subtracting to each point the endogenous contribution. Then, the results were automatically corrected for extraction recoveries and matrix effect. Due to the chromatographic coelution of PCB 77 with PCB 110 and PCB 170 with PCB 190, given concentrations express the sum of these compound pairs. 


\section{Results and Discussion}

\subsection{Method Performances}

Matrix-free calibration curves showed linearity always associated to $R^{2}>0.995$, and matrixmatched calibration curves provided $R^{2}$ between 0.980 and 0.999 . Method LOQ ranged $0.5-9.5 \mathrm{ng} / \mathrm{g}$ for PCBs; $1.0-14.0 \mathrm{ng} / \mathrm{g}$ for BDEs, except for BDE 209 value equal to $250.0 \mathrm{ng} / \mathrm{g}$; $1.2-248.2 \mathrm{ng} / \mathrm{g}$ for nBFRs; and 5.0-157.0 ng/g for PFAS. The sample preparation (Section 2.4) allowed for the simultaneous extraction and purification of a broad and heterogeneous group of compounds Considering the number of analytes monitored, total recoveries $\geq 40 \%$ were acceptable if associated to an RSD $\leq 20$. A lower extraction selectivity affects the quantitative analysis, due to the higher background and matrix effect. Nevertheless, recoveries above $50 \%$ were detected for most compounds $(97 \%)$, with recoveries ranging $85-115 \%$ for $72 \%$ of the analytes. The recovery obtained were in the range $70-96 \%$ for PCBs, $86-106 \%$ for BDEs, $41-116 \%$ for nBFRs, and $57-97 \%$ for PFAS. The intra- and inter-day repeatabilities expressed as RSD were below $10 \%$ and $12 \%$, respectively.

\subsection{Indoor Sample Analysis}

Tables 2-4 show the detected concentrations for PCBs, BDEs, and nBFRs, respectively. In the tables, n.d. indicates not detected compounds, while values between LOD and LOQ were considered positive and reported as $<$ LOQ. Columns $2-6$ display the specific values relative to each sampling site (D1-D5) of the investigated compounds, and the last row shows the total contribution associated to the same pollutant class expressed as a sum ( $\Sigma$ BDEs, $\Sigma$ nBFRs, and $\Sigma$ PCBs). Columns 7 and 8 present the pollutant-specific averages of domestic dusts (D1 and D2) and workplaces dusts (D3-D5), respectively, to easily compare the two different scenarios.

Table 2. PCB values expressed as ng/g of dust, reported for each congener, in the different indoor environments (Columns 2-6). Columns 7 and 8 show the domestic dust average (D1 and D2) and workplace dust average (D3-D5). The reported values were associated to a method RSD of 15\%.

\begin{tabular}{|c|c|c|c|c|c|c|c|}
\hline Compound & $\begin{array}{c}\text { D1 } \\
\text { (ng/g) }\end{array}$ & $\begin{array}{c}\text { D2 } \\
\text { (ng/g) }\end{array}$ & $\begin{array}{c}\text { D3 } \\
\text { (ng/g) }\end{array}$ & $\begin{array}{c}\text { D4 } \\
\text { (ng/g) }\end{array}$ & $\begin{array}{c}\text { D5 } \\
\text { (ng/g) }\end{array}$ & $\begin{array}{c}\text { Houses } \\
\text { Average }(\mathrm{ng} / \mathrm{g})\end{array}$ & $\begin{array}{c}\text { Workplaces } \\
\text { Average (ng/g) }\end{array}$ \\
\hline PCB $77+110$ & ${ }^{1}$ n.d. & ${ }^{1}$ n.d. & 150.3 & ${ }^{1}$ n.d. & 204.9 & & 177.6 \\
\hline РСВ 81 & 24.9 & 9.7 & ${ }^{1}$ n.d. & 19.5 & ${ }^{1}$ n.d & 17.3 & 9.8 \\
\hline РСВ 99 & ${ }^{1}$ n.d. & ${ }^{1}$ n.d. & ${ }^{1}$ n.d. & ${ }^{1}$ n.d. & ${ }^{1}$ n.d. & & \\
\hline РCB 101 & ${ }^{1}$ n.d. & ${ }^{1}$ n.d. & 37.4 & ${ }^{1}$ n.d. & ${ }^{1}$ n.d & & 18.7 \\
\hline PCB 105 & ${ }^{1}$ n.d. & ${ }^{1}$ n.d. & ${ }^{1}$ n.d. & ${ }^{1}$ n.d. & 56.6 & & 56.6 \\
\hline РCB 114 & 7.3 & 7.0 & ${ }^{1}$ n.d. & ${ }^{1}$ n.d. & ${ }^{1}$ n.d. & 7.2 & \\
\hline PCB 126 & ${ }^{1}$ n.d. & ${ }^{1}$ n.d. & ${ }^{1}$ n.d. & ${ }^{1}$ n.d. & 3.9 & & 3.9 \\
\hline PCB 138 & ${ }^{1}$ n.d. & 11.0 & 10.2 & 31.2 & 83.4 & 11.0 & 41.6 \\
\hline PCB 146 & $<2.8$ & $<2.8$ & ${ }^{1}$ n.d. & 3.7 & 12.7 & & 8.2 \\
\hline РCB 151 & ${ }^{1}$ n.d. & ${ }^{1}$ n.d. & ${ }^{1}$ n.d. & ${ }^{1}$ n.d. & ${ }^{1}$ n.d. & & \\
\hline PCB 156 & ${ }^{1}$ n.d. & 4.7 & ${ }^{1}$ n.d. & 5.1 & 11.2 & 4.7 & 8.1 \\
\hline PCB 157 & ${ }^{1}$ n.d. & 8.5 & ${ }^{1}$ n.d. & ${ }^{1}$ n.d. & 8.8 & 8.5 & 8.8 \\
\hline PCB 167 & ${ }^{1}$ n.d. & 10.1 & ${ }^{1}$ n.d. & ${ }^{1}$ n.d. & 13.3 & 10.1 & 13.3 \\
\hline PCB 169 & ${ }^{1}$ n.d. & ${ }^{1}$ n.d. & ${ }^{1}$ n.d. & ${ }^{1}$ n.d. & ${ }^{1}$ n.d. & & \\
\hline РСВ $170+190$ & 4.4 & 5.2 & ${ }^{1}$ n.d. & 13.8 & 24.7 & 4.8 & 19.3 \\
\hline PCB 177 & ${ }^{1}$ n.d. & 2.9 & ${ }^{1}$ n.d. & 6.0 & 17.6 & 2.9 & 11.8 \\
\hline PCB 180 & 8.7 & 12.7 & 5.0 & 33.0 & 65.1 & 10.7 & 34.4 \\
\hline РСB 183 & 18.3 & 17.4 & ${ }^{1}$ n.d. & 19.8 & 24.8 & 17.9 & 22.3 \\
\hline РCB 187 & $<1.4$ & $<1.4$ & ${ }^{1}$ n.d. & 8.2 & 19.0 & & 13.6 \\
\hline $2 \Sigma \mathrm{PCBs}$ & 63.6 & 89.3 & 203.0 & 140.4 & 546.1 & 76.4 & 296.5 \\
\hline
\end{tabular}

Values between LOD and LOQ were considered positive and reported as $<$ LOQ value. ${ }^{1}$ n.d., not detected. ${ }^{2} \Sigma$ PCBs is the sum of PCB concentrations. 
Table 3. BDE values expressed as ng/g of dust, reported for each congener, in the different indoor environments (Columns 2-6). Columns 7 and 8 show the total average value of the domestic dust average (D1 and D2) and workplace dust average (D3-D5). The Column 2-8 values were associated to a method RSD of 15\%. Results are compared with other studies (last two columns) reported as median (min.-max.) concentrations.

\begin{tabular}{|c|c|c|c|c|c|c|c|c|c|}
\hline Compound & $\begin{array}{c}\text { D1 } \\
\text { (ng/g) }\end{array}$ & $\begin{array}{c}\text { D2 } \\
\text { (ng/g) }\end{array}$ & $\begin{array}{c}\text { D3 } \\
\text { (ng/g) }\end{array}$ & $\begin{array}{c}\text { D4 } \\
\text { (ng/g) }\end{array}$ & $\begin{array}{c}\text { D5 } \\
\text { (ng/g) }\end{array}$ & $\begin{array}{l}\text { Houses Average } \\
\text { (ng/g) }\end{array}$ & $\begin{array}{c}\text { Workplaces Average } \\
\text { (ng/g) }\end{array}$ & $\begin{array}{c}\text { Fromme et al. [32] } \\
\text { (ng/g) }\end{array}$ & $\begin{array}{c}\text { de la Torre et al. [33] } \\
\text { (ng/g) }\end{array}$ \\
\hline BDE 28 & ${ }^{1}$ n.d. & ${ }^{1}$ n.d. & ${ }^{1}$ n.d. & ${ }^{1}$ n.d. & ${ }^{1}$ n.d. & & & & $0.08(<0.03-0.36)$ \\
\hline BDE 47 & 13.8 & 25.4 & 12.1 & 42.1 & 38.3 & 19.6 & 30.8 & $11.7(1.3-52.3)$ & $2.74(0.08-23.1)$ \\
\hline BDE 49 & ${ }^{1}$ n.d. & ${ }^{1}$ n.d. & ${ }^{1}$ n.d. & ${ }^{1}$ n.d. & ${ }^{1}$ n.d. & & & & \\
\hline BDE 66 & ${ }^{1}$ n.d. & ${ }^{1}$ n.d. & 53.8 & ${ }^{1}$ n.d. & ${ }^{1}$ n.d. & & 53.8 & & $(<0.02-0.40)$ \\
\hline BDE 85 & ${ }^{1}$ n.d. & ${ }^{1}$ n.d. & ${ }^{1}$ n.d. & ${ }^{1}$ n.d. & ${ }^{1}$ n.d. & & & & $0.19(<0.01-3.7)$ \\
\hline BDE 99 & 20.5 & 54.4 & 23.6 & 56.5 & 58.8 & 37.4 & 46.3 & $21.7(1.0-84.1)$ & $4.97(0.11-46.7)$ \\
\hline BDE 100 & 47.9 & 20.5 & 6.4 & ${ }^{1}$ n.d. & 51.9 & 34.2 & 29.2 & $3.5(2.0-15.8)$ & $0.65(0.03-6.83)$ \\
\hline BDE 153 & ${ }^{1}$ n.d. & ${ }^{1}$ n.d. & ${ }^{1}$ n.d. & ${ }^{1}$ n.d. & ${ }^{1}$ n.d. & & 16.1 & $4.6(2.0-20.5)$ & $0.78(<0.02-6.47)$ \\
\hline BDE 154 & ${ }^{1}$ n.d. & 6.4 & 2.0 & ${ }^{1}$ n.d. & 9.0 & 6.4 & 5.5 & $2.5(2.0-9.5)$ & $2.59(<0.04-25.3)$ \\
\hline BDE 183 & ${ }^{1}$ n.d. & 12.4 & 12.5 & 134.4 & 74.3 & 12.4 & 73.7 & $27.9(2.0-394)$ & $1.11(0.1-22.9)$ \\
\hline BDE 197 & ${ }^{1}$ n.d. & ${ }^{1}$ n.d. & ${ }^{1}$ n.d. & ${ }^{1}$ n.d. & ${ }^{1}$ n.d. & & & & \\
\hline BDE 209 & ${ }^{1}$ n.d. & ${ }^{1}$ n.d. & ${ }^{1}$ n.d. & ${ }^{1}$ n.d. & 2368.0 & & 2368.0 & & $232(5.36-2470)$ \\
\hline${ }^{2} \Sigma$ BDEs & 82.2 & 119.0 & 126.5 & 233.0 & 2600.3 & 100.6 & 986.6 & & \\
\hline
\end{tabular}

Values between LOD and LOQ were considered positive and reported as $<$ LOQ value. ${ }^{1}$ n.d., not detected. ${ }^{2} \Sigma B D E s$ is the sum of BDE concentrations. 
Table 4. nBFR values expressed as ng/g of dust, reported for each congener, in the different indoor environments (Columns 2-6). Columns 7 and 8 show the total average value of the domestic dust average (D1 and D2) and workplace dusts average (D3-D5). The Column 2-8 values were associated to a method RSD of 15\%. Results are compared with other studies (last two columns) reported as median (min.-max.) concentrations.

\begin{tabular}{|c|c|c|c|c|c|c|c|c|c|}
\hline Compound & $\begin{array}{c}\text { D1 } \\
\text { (ng/g) }\end{array}$ & $\begin{array}{c}\text { D2 } \\
\text { (ng/g) }\end{array}$ & $\begin{array}{c}\text { D3 } \\
\text { (ng/g) }\end{array}$ & $\begin{array}{c}\text { D4 } \\
\text { (ng/g) }\end{array}$ & $\begin{array}{c}\text { D5 } \\
\text { (ng/g) }\end{array}$ & $\begin{array}{c}\text { Houses Average } \\
\text { (ng/g) }\end{array}$ & $\begin{array}{c}\text { Workplaces Average } \\
\text { (ng/g) }\end{array}$ & $\begin{array}{c}\text { Fromme et al. [32] } \\
(\mathrm{ng} / \mathrm{g})\end{array}$ & $\begin{array}{c}\text { de la Torre et al. [33] } \\
\text { (ng/g) }\end{array}$ \\
\hline ТВВРА & ${ }^{1}$ n.d. & ${ }^{1}$ n.d. & ${ }^{1}$ n.d. & 32320.10 & $<248.2$ & & $32,320.1$ & $44.1(2.9-233)$ & \\
\hline TBPH & 182.9 & 464.5 & 64.5 & $<44$ & $<44$ & 323.7 & 64.5 & $20(25-2274)$ & \\
\hline TBB & 12.0 & 11.7 & ${ }^{1}$ n.d. & 9.6 & 9.7 & 11.9 & 9.7 & $4.2(<3.0-13.6)$ & \\
\hline TBP & 26.4 & 51.7 & 16.7 & 788.4 & 54.4 & 39.0 & 286.5 & & \\
\hline BTBPE & ${ }^{1}$ n.d. & ${ }^{1}$ n.d. & 17.6 & 124.7 & 26.2 & & 56.2 & $7(<10-34)$ & $1.67(<0.07-26.9)$ \\
\hline DPTE & ${ }^{1}$ n.d. & ${ }^{1}$ n.d. & 5.4 & 58.1 & ${ }^{1}$ n.d. & & 31.7 & & \\
\hline ATE & ${ }^{1}$ n.d. & ${ }^{1}$ n.d. & 14.5 & ${ }^{1}$ n.d. & ${ }^{1}$ n.d. & & 14.5 & & \\
\hline HBB & ${ }^{1}$ n.d. & ${ }^{1}$ n.d. & 28.3 & 24.2 & 138.2 & & 63.6 & & $0.36(<0.003-2.11)$ \\
\hline $\mathrm{HCDBCO}$ & 32.0 & ${ }^{1}$ n.d. & 40.4 & ${ }^{1}$ n.d. & ${ }^{1}$ n.d. & 32.0 & 40.4 & & \\
\hline PBBA & 6.4 & 4.6 & 14.2 & 15.8 & ${ }^{1}$ n.d. & 5.5 & 15.0 & & \\
\hline PBEB & $<2.2$ & $<2.2$ & ${ }^{1}$ n.d. & 4.1 & $<2.2$ & & 4.1 & & $0.06(<0.003-0.25)$ \\
\hline TBCO & ${ }^{1}$ n.d. & ${ }^{1}$ n.d. & $<26.7$ & $<26.7$ & 40.7 & & 40.7 & & \\
\hline TBECH & 41.8 & 33.7 & 38.3 & 41.5 & 228.7 & 37.7 & 102.8 & & \\
\hline${ }^{2} \Sigma$ nBFRs & 301.4 & 566.2 & 239.9 & 33386.5 & 497.8 & 433.8 & $11,374.7$ & & \\
\hline
\end{tabular}

Values between LOD and LOQ were considered positive and reported as $<$ LOQ value. ${ }^{1}$ n.d., not detected. ${ }^{2} \Sigma$ nBFRs is the sum of nBFR concentrations. 
PCB 99, РCB 151, and PCB 169 were not detected in any sample and only PCB 180 was detected in all samples. The total contribution of PCBs contamination, expressed as the sum of homologs concentration ( $\Sigma \mathrm{PCBs}$ ), was higher in workplaces than in domestic dust. In particular, D5 values result about four times higher than D4, possibly because of the larger workshop size and older devices stored in D5 workshop. D4 and D5 results were also above the concentration found for similar workplace category in other studies [26,34]. In the absence of a specific limit for PCBs in dust, we compared the obtained concentrations with the value reported from EPA (Environmental Protection Agency) for the soil in Regional Screening Level Tables, equal to $0.22 \mu \mathrm{g} / \mathrm{g}$ [35]. In D5, PCB concentration $(0.55 \mu \mathrm{g} / \mathrm{g})$ exceeded more than twice the EPA value. Furthermore, we monitored eight dioxin-like PCBs (DL PCBs), due to the health concern about these substances. $\Sigma$ DL PCBs was 32.2, 40.0, 150.3, 24.6 , and $298.7 \mathrm{ng} / \mathrm{g}$ for D1-D5, respectively. The percentage of $\Sigma$ DL PCBs concentrations versus total PCBs concentrations ( $\Sigma$ PCBs) was around or above $50 \%$ for all samples except for D4, indicating that these harmful compounds can be still found.

As can be seen in Table 3, BDE 28, BDE 85, and BDE 197 were not detected in any sample, whereas BDE 47 and BDE 99 were found in all samples. Similar to PCBs, $\Sigma$ BDEs was higher in electronic and mechanical workshops (D4 and D5). BDE 209 is the most widespread BDE and it was found in high concentrations in several studies [36-38]. In our work, BDE 209 was detected only in one sample (D5) and it represented the most concentrated (2368.0 ng/g) compound among BDEs investigated. As shown in Table 3, the values obtained for each congener were within the contamination range reported in other studies, except for BDE 100 that resulted two and five times higher than in the studies of Fromme [32] and de la Torre [33], respectively.

Among nBFRs, the most concentrated compound was TBBPA in D4, detected at a concentration of $32,320.1 \mathrm{ng} / \mathrm{g}$. In this study, TBBPA was not detected in the other samples, possibly because of the high LOD of our method $(124.1 \mathrm{ng} / \mathrm{g})$. D4 concentration was two orders of magnitude higher compared to TBBPA concentrations in other indoor dust studies $[9,36,39]$. However, high TBBPA concentrations were found in workplaces where similar activities were carried out, such as dismantling of electronic devices in recycling plants [40]. The high contamination level of TBBPA in D4 can be explained considering the workers practice to remove the dust stored inside the devices before repairing them. In fact, TBBPA, added in many resins used in plastic casings of electronic devices [9], was found in high concentrations in computer cooling fan parts. Many FRs are frequently added in those parts because of the risk of overheating due to the accumulated dust between the plug and the wall outlet [41]. About the other 12 nBFRs, BTBPE average values were higher than other studies [32,33,38,42] and HBB showed average values about ten times higher than the literature values $[33,36,38,42]$. TBP and TBPH were detected in all samples, in agreement with other studies (100\% of samples incidence) [32,43]. TBP values were $788.4 \mathrm{ng} / \mathrm{g}$ in D4 and $464.5 \mathrm{ng} / \mathrm{g}$ in D1, while TBPH was higher in D1 and D2 (182.9 and $464.5 \mathrm{ng} / \mathrm{g}$ respectively). TBPH had a large commercial use as Firemaster 550 mixed with TBB (ratio of 1:4) but, in the present study, a TBPH concentration higher than TBB was found, in accordance with other studies [42,44], due to the faster transfer of TBB than TBP. Nevertheless, not accounting for TBPH contamination, the total concentration ( $\Sigma$ nBFRs) results higher in electronic and mechanical workshops (D4 and D5) than in houses and office dusts.

Regarding the PFAS, PFOA was the only detected compound with a concentration lower than the LOQ (119.3 ng/g) in both D4 and D5 samples, while PFBS, PFOS, PFTeDA, and FOSA were not detected in any samples.

To have a complete view of the indoor pollution and in the perspective of a cumulative exposure assessment to environmental pollutants, thanks to the versatility of our method, the samples were also analyzed to determine the PAHs. Sums of PAHs ( $\Sigma$ PAHs and $\Sigma$ (nitro-PAHs + oxy-PAHs)) were calculated. $\Sigma$ PAHs were 417.2, 5247.9, 1720.2, 4917.6, and 7601.4 ng/g for D1-D5, respectively, while $\Sigma$ (nitro-PAHs + oxy-PAHs) were 733.1, 495.7, 145.5, 3447.2, and 5110.9 ng/g for D1-D5, respectively. PAHs and PAH derivatives were generated from outdoor combustion processes. The results assess that indoor contamination strongly depends on the outdoor environment. It should be noted that the D1 
sample, collected in a suburban apartment, showed less contamination for PAHs and PAH derivatives than the other samples, collected in a central area of the city of Rome, strongly characterized by motor vehicle traffic.

\subsection{Estimate of Human Exposure}

To evaluate the human exposure, EDI (estimated daily intake) was calculated for PCBs, PBDEs, and the main nBFRs detected. EDIs were calculated for each environment separately rather than using the domestic and workplace averaged concentrations, since they were not considered representative because of the small number of samples treated in this preliminary study. Settled dust can be unintentionally ingested via passive deposition onto the surface of the buccal, nasal, and ocular mucous membranes as well as hand-to-mouth activity. In addition, dermal adsorption can also contribute to the exposure. These exposure contributions were calculated as $\mathrm{EDI}_{\text {ingestion }}$ and $\mathrm{EDI}_{\mathrm{dermal}}$ using the following formulas [33]:

$$
\begin{gathered}
\mathrm{EDI}_{\text {ingestion }}=\left(\mathrm{C}_{\text {dust }} \times \mathrm{IR}_{\text {dust }} \times \mathrm{AF}_{\text {gastro }} \times \mathrm{EF}\right) / \mathrm{BW} \\
\mathrm{EDI}_{\text {dermal }}=\left(\mathrm{C}_{\text {dust }} \times \mathrm{DAS} \times \mathrm{ESA} \times \mathrm{AF}_{\text {dermal }} \times \mathrm{EF}\right) / \mathrm{BW}
\end{gathered}
$$

The used parameters are summarized in Tables 5 and $6 . C_{\text {dust }}$ is the experimental pollutant concentration, $\mathrm{IR}_{\text {dust }}$ represents the amount of unintentional dust ingestion rate per day, $\mathrm{AF}_{\text {gastro }}$ is the percentage amount of pollutant adsorbed gastrointestinally, and the indoor exposure fraction (EF) represents the percentage of time spent in indoor environments in a day;, hence, different values were used for domestic dusts (D1 and D2) and workplace dusts (D3-D5). For dermal adsorption calculation, the dust adherent to skin (DAS) and the dermal adsorption factor $\left(\mathrm{AF}_{\text {dermal }}\right)$ were used. $\mathrm{AF}_{\text {dermal }}$ has a specific parameter for each pollutant (Tables 5 and 6). It was not available for some nBFRs; thus, according to Tay et al. [45], factors associated to other similar compounds, considering the molecular weight and the number of bromines, were chosen. In particular, we used the BDE 99 value for PBBA. Because of the absence of children in the environment studied, only adult values were used for body weight (BW) and exposed skin area (ESA). To avoid underestimation, we preferred the worst-case scenario values when different values could be used.

Table 5. Parameters used for $\mathrm{EDI}_{\text {ingestion }}$ and $\mathrm{EDI}_{\mathrm{dermal}}$ calculation.

\begin{tabular}{ccc}
\hline Parameter & & Reference \\
\hline IR $_{\text {dust }}$ & $60 \mathrm{mg} /$ day & {$[46]$} \\
$\mathrm{AF}_{\text {gastro }}$ for BDEs and nBFRs & $100 \%$ & {$[47,48]$} \\
$\mathrm{AF}_{\text {gastro for PCBs }}$ & $85 \%$ & {$[49]$} \\
EF home & $64 \%$ & {$[50]$} \\
EF workplace & $22 \%$ & {$[50]$} \\
DAS & $0.1 \mathrm{mg} / \mathrm{cm}^{2}$ & {$[50]$} \\
BW & $80 \mathrm{~kg}$ & {$[51]$} \\
ESA & $4615 \mathrm{~cm}^{2}$ & {$[52]$} \\
\hline
\end{tabular}

Table 7 shows the values obtained. For each environment, $\mathrm{EDI}_{\text {ingestion }}$ and $\mathrm{EDI}_{\mathrm{dermal}}$ were summed and are reported as $\Sigma \mathrm{EDI}_{\text {(ingestion+dermal) }}$. However, it is worth noting that the major indoor dust

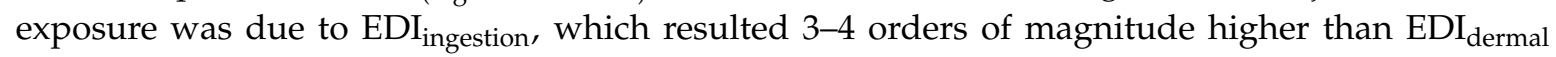
in all the cases (data not shown). In addition, the overall contribution of each pollutant class as $\Sigma$ EDI $\Sigma$ PCBs, $\Sigma$ EDI BDEs, and $\Sigma$ EDI nBFRs are reported. The total estimated $\Sigma E_{\text {EDI }}$ (ingestion+dermal) of each compound was compared with the reference dose available (RfD, Table 7). RfD was the assumed daily exposure related to no appreciable risk of deleterious effects during a lifetime. In particular, the $\Sigma$ EDI (ingestion+dermal) for PCBs were in the range of $1976.3-7687.3 \mathrm{pg} / \mathrm{kg}$ bw/day, with the mechanical workshop (D5 dust) giving the highest exposure. However, the $\Sigma \mathrm{EDI}_{\text {(ingestion+dermal) }}$ for PCB resulted always lower than $6 \%$ of RfD reported. The $\Sigma E D I_{(\text {ingestion+dermal) }}$ for BDEs were in the 
range of $2103.8-430,05.0 \mathrm{pg} / \mathrm{kg}$ bw/day; in this case as well, the mechanical workshop (D5) was related to the highest exposure. For the other workplaces, despite higher concentrations revealed in dust, the $\Sigma \mathrm{EDI}_{\text {(ingestion+dermal) }}$ resulted less than or equal to domestic exposures, because of the different $\mathrm{EF}$ factor used. In none of the environments, the $\Sigma \mathrm{EDI}_{\text {(ingestion+dermal }}$ ) was higher than $3 \%$ of RfD. Finally, the highest exposure contribution was associated to nBFRs; the $\Sigma \operatorname{EDI}_{\text {(ingestion+dermal) }}$ values were in the range of 3968.2-555,694.2 pg/kg bw/day. The electronic repair workshop (D4) gave the highest value, but, also in this case, the other workplaces led to lower or similar exposures compared to domestic environments. In any case, the $\Sigma \mathrm{EDI}_{\text {(ingestion+dermal) }}$ related to nBFRs resulted in less than $0.05 \%$ of RfD available.

Table 6. List of $\mathrm{AF}_{\mathrm{dermal}}$ factor used in this study.

\begin{tabular}{ccc}
\hline Compound & Percent & Reference \\
\hline BDE 28 & 27 & {$[53]$} \\
BDE 47 & 33 & {$[53]$} \\
BDE 49 & 33 & {$[53]$} \\
BDE 66 & 33 & {$[53]$} \\
BDE 85 & 34 & {$[53]$} \\
BDE 99 & 34 & {$[53]$} \\
BDE 100 & 34 & {$[53]$} \\
BDE 153 & 37 & {$[53]$} \\
BDE 154 & 37 & {$[53]$} \\
BDE 183 & 37 & {$[53]$} \\
BDE 197 & 8 & {$[53]$} \\
BDE 209 & 8 & {$[53]$} \\
TBBPA & 40 & {$[50]$} \\
TBPH & 8 & {$[53]$} \\
TBB & 11 & {$[53]$} \\
TBP & 11 & {$[53]$} \\
BTBPE & 11 & {$[54]$} \\
HBB & 11 & {$[45]$} \\
PBBA & 34 & \\
TBECH & 27 & {$[45]$} \\
\hline
\end{tabular}

To sum up, the $\Sigma \operatorname{EDI}_{\text {(ingestion+dermal) }}$ values obtained were several orders of magnitude lower than $\mathrm{RfD}$, indicating that the dust contamination in the environment investigated was not of health concern. However, the high concentrations of some FRs in both domestic and occupational environments suggest complementary air sampling of those compounds to have information about inhalation exposure as well.

Even though many data are available about human exposure to legacy PCBs and BDEs, there is still a lack of information about nBFRs exposure. The accurate environmental distribution and human exposure of emerging pollutants such as nBFRs, together with toxicological data, are fundamental findings for risk assessment by authorities and for proposing regulation directives. This explorative study may be the basis for further studies, applying the proposed methodology to an extensive number of samples. 
Table 7. The sum $\Sigma E D I($ ingestion+dermal) obtained for each different environment (D1-D5) is presented (Columns 2-6). The total contribution for each pollutant was calculated as $\Sigma E D I$ PCBs, $\Sigma E D I$ BDEs, and $\Sigma E D I$ nBFRs. RfD is also reported. The values are expressed as ng/kg bw/day.

\begin{tabular}{|c|c|c|c|c|c|c|}
\hline & D1 & D2 & D3 & D4 & D5 & \\
\hline & $\Sigma E^{\prime} I_{\text {(ingestion+dermal) }}$ & $\Sigma E^{\prime} I_{\text {(ingestion+dermal) }}$ & $\Sigma \mathrm{EDI}_{(\text {ingestion+dermal) }}$ & $\Sigma$ EDI $_{\text {(ingestion+dermal) }}$ & $\Sigma E I_{\text {(ingestion+dermal) }}$ & RfD [Ref] \\
\hline РCB $77+110$ & & & 2.1 & & 2.9 & $4.0 \times 10^{+1}$ \\
\hline РCB 81 & 1.0 & $4.0 \times 10^{-1}$ & & $2.7 \times 10^{-1}$ & & $2.0 \times 10^{+1}[55]$ \\
\hline PCB 101 & & & $5.3 \times 10^{-1}$ & & & $2.0 \times 10^{+1}[55]$ \\
\hline PCB 105 & & & & & $8.0 \times 10^{-1}$ & $2.0 \times 10^{+1}[55]$ \\
\hline РСВ 114 & $3.0 \times 10^{-1}$ & $2.9 \times 10^{-1}$ & & & & $2.0 \times 10^{+1}[55]$ \\
\hline РСВ 126 & & & & & $5.4 \times 10^{-2}$ & $2.0 \times 10^{+1}[55]$ \\
\hline PCB 138 & & $4.5 \times 10^{-1}$ & $1.4 \times 10^{-1}$ & $4.4 \times 10^{-1}$ & 1.2 & $2.0 \times 10^{+1}[55]$ \\
\hline PCB 146 & & & & $5.2 \times 10^{-2}$ & $1.8 \times 10^{-1}$ & $2.0 \times 10^{+1}$ \\
\hline PCB 156 & & $1.9 \times 10^{-1}$ & & $7.2 \times 10^{-2}$ & $1.6 \times 10^{-1}$ & $2.0 \times 10^{+1}$ \\
\hline PCB 157 & & $3.5 \times 10^{-1}$ & & & $1.2 \times 10^{-1}$ & $2.0 \times 10^{+1}[55]$ \\
\hline PCB 167 & & $4.1 \times 10^{-1}$ & & & $1.9 \times 10^{-1}$ & $2.0 \times 10^{+1}[55]$ \\
\hline PCB $170+190$ & $1.8 \times 10^{-1}$ & $2.1 \times 10^{-1}$ & & $1.9 \times 10^{-1}$ & $3.5 \times 10^{-1}$ & $4.0 \times 10^{+1}[55]$ \\
\hline PCB 177 & & $1.2 \times 10^{-1}$ & & $8.5 \times 10^{-2}$ & $2.5 \times 10^{-1}$ & $2.0 \times 10^{+1}[55]$ \\
\hline PCB 180 & $3.5 \times 10^{-1}$ & $5.2 \times 10^{-1}$ & $7.1 \times 10^{-2}$ & $4.6 \times 10^{-1}$ & $9.2 \times 10^{-1}$ & $2.0 \times 10^{+1}[55]$ \\
\hline PCB 183 & $7.5 \times 10^{-1}$ & $7.1 \times 10^{-1}$ & & $2.8 \times 10^{-1}$ & $3.5 \times 10^{-1}$ & $2.0 \times 10^{+1}[55]$ \\
\hline PCB 187 & & & & $1.2 \times 10^{-1}$ & $2.7 \times 10^{-1}$ & $2.0 \times 10^{+1}[55]$ \\
\hline$\Sigma$ EDI PCBs & 2.6 & 3.6 & 2.9 & 2.0 & 7.7 & \\
\hline BDE 47 & $6.7 \times 10^{-1}$ & 1.2 & $2.0 \times 10^{-1}$ & $7.0 \times 10^{-1}$ & $6.4 \times 10^{-1}$ & $1.00 \times 10^{+2}[56]$ \\
\hline BDE 66 & & & $8.9 \times 10^{-1}$ & & & $1.00 \times 10^{+2}[56]$ \\
\hline BDE 99 & $9.9 \times 10^{-1}$ & 2.6 & $3.9 \times 10^{-1}$ & $9.4 \times 10^{-1}$ & $9.8 \times 10^{-1}$ & $1.00 \times 10^{+2}[56]$ \\
\hline BDE 100 & 2.3 & $9.9 \times 10^{-1}$ & $1.1 \times 10^{-1}$ & & $8.6 \times 10^{-1}$ & $1.00 \times 10^{+2}[48]$ \\
\hline BDE 153 & & & $2.7 \times 10^{-1}$ & & & $2.00 \times 10^{+2}[56]$ \\
\hline BDE 154 & & $3.1 \times 10^{-1}$ & $3.3 \times 10^{-2}$ & & $1.5 \times 10^{-1}$ & $1.00 \times 10^{+1}[48]$ \\
\hline BDE 183 & & $6.0 \times 10^{-1}$ & $2.1 \times 10^{-1}$ & 2.2 & 1.2 & $2.00 \times 10^{+2}[56]$ \\
\hline BDE 209 & & & & & $3.9 \times 10^{+1}$ & $7.00 \times 10^{+3}[56]$ \\
\hline$\Sigma$ EDI BDEs & 4.0 & 5.7 & 2.1 & 3.9 & $4.3 \times 10^{+1}$ & \\
\hline TBP & 1.3 & 2.5 & $2.8 \times 10^{-1}$ & $1.3 \times 10^{+1}$ & $9.0 \times 10^{-1}$ & $9.2 \times 10^{+4}[55,57]$ \\
\hline BTBPE & & & $2.9 \times 10^{-1}$ & 2.1 & $4.3 \times 10^{-1}$ & $2.00 \times 10^{+4}[58]$ \\
\hline HBB & & & $4.7 \times 10^{-1}$ & $4.0 \times 10^{-1}$ & 2.3 & $2.00 \times 1^{+3}[33]$ \\
\hline PBBA & $3.1 \times 10^{-1}$ & $2.2 \times 10^{-1}$ & $2.4 \times 10^{-1}$ & $2.6 \times 10^{-1}$ & & \\
\hline TBB & $5.8 \times 10^{-1}$ & $5.6 \times 10^{-1}$ & & $1.6 \times 10^{-1}$ & $1.6 \times 10^{-1}$ & $2.00 \times 10^{+4}[58]$ \\
\hline TBECH & 2.0 & 1.6 & $6.4 \times 10^{-1}$ & $6.9 \times 10^{-1}$ & 3.8 & $6.8 \times 10^{+3}[59]$ \\
\hline TBPH & 8.8 & $2.2 \times 10^{+1}$ & 1.1 & & & $2.00 \times 10^{+4}[60]$ \\
\hline TBBPA & & & & $5.4 \times 10^{+2}$ & & $6.00 \times 10^{+5}[61]$ \\
\hline$\Sigma$ EDI nBFRs & $1.3 \times 10^{+1}$ & $2.7 \times 10^{+1}$ & 3.0 & $5.5 \times 10^{+2}$ & 7.6 & \\
\hline
\end{tabular}




\section{Conclusions}

In this study, we monitored 21 PCBs, 12 BDEs, 13 nBFR, and 5 PFAS together with 20 PAHs and 28 PAH derivatives (nitro-PAHs and oxy-PAHs) in settled indoor dust. A unique sample treatment was optimized for simultaneous extraction of the 99 pollutants, obtaining acceptable analytical performance for such an explorative study. Domestic and occupational environments were considered, namely the dusts from two homes, one office, and two dusts of electronic and mechanical workshops were analyzed. The electronic and mechanical workshops showed the highest contamination for legacy FRs as PCBs and BDEs. The contamination by nBFRs was heterogeneous; in particular, TBBPA and TBP in D4 and TBPH in D2 were detected in higher concentrations. The preliminary investigation of PFAS showed only for PFOA detectable concentrations above LOQ in mechanical and electronical workshops. Because of the PFOS and PFOA phase out from the market, analysis of alternatively used PFAS will be the next step in future studies. Contamination by PAHs was, as expected, stronger in the samples collected in the central area of Rome than in D1 sample collected in suburbs area.

To assess contaminated dust contribution to human exposure, we calculated pollutants EDI as the sum of unintentional ingestion and dermal adsorption pathways. Despite the higher pollutant concentrations in workshops, EDI by PCBs and BDEs showed a similar contribution in both domestic and workshop scenarios, because of the different amounts of time spent in these environments (EF factor). Higher EDI values were related to nBFRs in all samples except for D5 environment. The EDI values were several orders of magnitude below the RfD available, suggesting that the exposure to dust may not pose a health risk in the investigated buildings. The significant concentrations of some FRs found in this explorative survey indicate that both domestic and occupational scenarios should be monitored. In addition, air concentrations of those contaminants may useful to fully characterize the indoor pollutant distribution and exposure. The proposed indoor dust method, characterized by rapid and cheaper sampling, can be applied to more houses and different workplaces in further studies to delve into the topic about the indoor environment pollution, required to reduce contaminant exposure to humans.

Author Contributions: Conceptualization, F.B.; Data curation, G.S. and E.S.; Funding acquisition, F.B.; Methodology, E.S.; Project administration, P.D.F., C.R., and D.P.; Validation, G.S. and E.S.; Writing-original draft, E.S.; and Writing-review and editing, P.D.F., C.R., D.P., and F.B. All authors have read and agreed to the published version of the manuscript. Funding: This research was funded by INAIL, grant number INAIL-Bric 2019-ID13.

Conflicts of Interest: The authors declare no conflict of interest.

\section{References}

1. Shaw, S.D.; Blum, A.; Weber, R.; Kannan, K.; Rich, D.; Lucas, D.; Koshland, C.P.; Dobraca, D.; Hanson, S.; Birnbaum, L.S. Halogenated flame retardants: Do the fire safety benefits justify the risks? Rev. Environ. Health 2010, 25, 261-305. [CrossRef]

2. Liang, R.; Chen, J.; Shi, Y.; Lu, Y.; Sarvajayakesavalu, S.; Xu, X.; Zheng, X.; Khan, K.; Su, C. Toxicological effects on earthworms (Eisenia fetida) exposed to sub-lethal concentrations of BDE-47 and BDE-209 from a metabolic point. Environ. Pollut. 2018, 240, 653-660. [CrossRef]

3. Darnerud, P.O. Brominated flame retardants as possible endocrine disrupters. Int. J. Androl. 2008, 31, $152-160$. [CrossRef]

4. Taheran, M.; Komtchou, S.; Lonappan, L.; Naji, T.; Brar, S.K.; Cledon, M.; Drogui, P. Environmental issues of Polybrominated Diphenyl Ethers. Crit. Rev. Environ. Sci. Technol. 2017, 47, 1107-1142. [CrossRef]

5. He, Y.; Peng, L.; Zhang, W.; Liu, C.; Yang, Q.; Zheng, S.; Bao, M.; Huang, Y.; Wu, K. Adipose tissue levels of polybrominated diphenyl ethers and breast cancer risk in Chinese women: A case-control study. Environ. Res. 2018, 167, 160-168. [CrossRef]

6. UNEP. Decision SC-4/14, Listing of Hexabromodiphenyl Ether and Heptabromodiphenyl Ether; UNEP: Nairobi, Kenya, 2009.

7. UNEP. Decision SC-4/18, Listing of Tetrabromodiphenyl Ether and Pentabromodiphenyl Ether; UNEP: Nairobi, Kenya, 2009. 
8. Stapleton, H.M.; Allen, J.G.; Kelly, S.M.; Konstantinov, A.; Klosterhaus, S.; Watkins, D.; Mcclean, M.D.; Webster, T.F. Alternate and new brominated flame retardants detected in U.S. house dust. Environ. Sci. Technol. 2008, 42, 9453-9454. [CrossRef]

9. Abafe, O.A.; Martincigh, B.S. Determination and human exposure assessment of polybrominated diphenyl ethers and tetrabromobisphenol A in indoor dust in South Africa. Env. Sci. Pollut. Res. 2016, 23, 7038-7049. [CrossRef] [PubMed]

10. Deng, J.; Liu, C.; Yu, L.; Zhou, B. Chronic exposure to environmental levels of tribromophenol impairs zebrafish reproduction. Toxicol. Appl. Pharmacol. 2010, 243, 87-95. [CrossRef]

11. Covaci, A.; Harrad, S.; Abdallah, M.A.E.; Ali, N.; Law, R.J.; Herzke, D.; de Wit, C.A. Novel brominated flame retardants: A review of their analysis, environmental fate and behaviour. Environ. Int. 2011, 37, 532-556. [CrossRef] [PubMed]

12. Qi, H.; Li, W.L.; Liu, L.Y.; Song, W.W.; Ma, W.L.; Li, Y.F. Brominated flame retardants in the urban atmosphere of Northeast China: Concentrations, temperature dependence and gas-particle partitioning. Sci. Total Environ. 2014, 491-492, 60-66. [CrossRef] [PubMed]

13. WHO/ICPS (World Health Organization/International Programme on Chemical Safety). Environmental Health Criteria 172. Tetrabromobisphenol A and Derivatives; WHO: Geneva, Switzerland, 1995.

14. Jans, U. Emerging Brominated Flame Retardants in Sediments and Soils: A Review. Curr. Pollut. Rep. 2016, 2, 213-223. [CrossRef]

15. Egloff, C.; Crump, D.; Chiu, S.; Manning, G.; McLaren, K.K.; Cassone, C.G.; Letcher, R.J.; Gauthier, L.T.; Kennedy, S.W. In vitro and in ovo effects of four brominated flame retardants on toxicity and hepatic mRNA expression in chicken embryos. Toxicol. Lett. 2011, 207, 25-33. [CrossRef] [PubMed]

16. Courtney, K.D.; Andrews, J.E. Teratogenic evaluation and fetal deposition of hexabromobenzene (hbb) and hexafluorobenzene (hfb) in cd-1 mice. J. Environ. Sci. Heal. B 1984, 19, 83-94. [CrossRef] [PubMed]

17. Ezechiáš, M.; Svobodová, K.; Cajthaml, T. Hormonal activities of new brominated flame retardants. Chemosphere 2012, 87, 820-824. [CrossRef] [PubMed]

18. Saunders, D.M.V.; Higley, E.B.; Hecker, M.; Mankidy, R.; Giesy, J.P. In vitro endocrine disruption and TCDD-like effects of three novel brominated flame retardants: TBPH, TBB, \& TBCO. Toxicol. Lett. 2013, 223, 252-259. [CrossRef]

19. Khalaf, H.; Larsson, A.; Berg, H.; McCrindle, R.; Arsenault, G.; Olsson, P.E. Diastereomers of the brominated flame retardant 1,2-dibromo-4-(1,2 dibromoethyl)cyclohexane induce androgen receptor activation in the HepG2 hepatocellular carcinoma cell line and the LNCaP prostate cancer cell line. Environ. Health Perspect. 2009, 117, 1853-1859. [CrossRef]

20. Melzer, D.; Rice, N.; Depledge, M.H.; Henley, W.E.; Galloway, T.S. Association between serum perfluorooctanoic acid (PFOA) and thyroid disease in the U.S. National Health and Nutrition Examination Survey. Environ. Health Perspect. 2010, 118, 686-692. [CrossRef]

21. Darrow, L.A.; Groth, A.C.; Winquist, A.; Shin, H.M.; Bartell, S.M.; Steenland, K. Modeled perfluorooctanoic acid (PFOA) exposure and liver function in a Mid-Ohio Valley community. Environ. Health Perspect. 2016, 124, 1227-1233. [CrossRef] [PubMed]

22. Fitz-Simon, N.; Fletcher, T.; Luster, M.I.; Steenland, K.; Calafat, A.M.; Kato, K.; Armstrong, B. Reductions in serum lipids with a 4-year decline in serum perfluorooctanoic acid and perfluorooctanesulfonic acid. Epidemiology 2013, 24, 569-576. [CrossRef]

23. Wang, N.; Szostek, B.; Buck, R.C.; Folsom, P.W.; Sulecki, L.M.; Gannon, J.T. 8-2 Fluorotelomer alcohol aerobic soil biodegradation: Pathways, metabolites, and metabolite yields. Chemosphere 2009, 75, 1089-1096. [CrossRef]

24. Stubbings, W.A.; Harrad, S. Extent and mechanisms of brominated flame retardant emissions from waste soft furnishings and fabrics: A critical review. Environ. Int. 2014, 71, 164-175. [CrossRef] [PubMed]

25. Buiarelli, F.; Di Filippo, P.; Pomata, D.; Riccardi, C.; Bartocci, M. A liquid chromatography tandem mass spectrometry method for simultaneous analysis of 46 atmospheric particulate-phase persistent organic pollutants and comparison with gas chromatography/mass spectrometry. Int. J. Environ. Anal. Chem. 2017, 97, 797-818. [CrossRef]

26. Pomata, D.; Di Filippo, P.; Riccardi, C.; Rossi, V.; Simonetti, G.; Sonego, E.; Buiarelli, F. Method optimisation for the simultaneous determination of legacy and emerging halogenated flame retardants in particulate matter collected in an electronic waste recycling facility. Int. J. Environ. Anal. Chem. 2019, 1-18. [CrossRef] 
27. Brown, F.R.; Whitehead, T.P.; Park, J.S.; Metayer, C.; Petreas, M.X. Levels of non-polybrominated diphenyl ether brominated flame retardants in residential house dust samples and fire station dust samples in California. Environ. Res. 2014, 135, 9-14. [CrossRef] [PubMed]

28. Fernández-Cruz, T.; Martínez-Carballo, E.; Simal-Gándara, J. Optimization of selective pressurized liquid extraction of organic pollutants in placenta to evaluate prenatal exposure. J. Chromatogr. A 2017, 1495, 1-11. [CrossRef] [PubMed]

29. Di Filippo, P.; Pomata, D.; Riccardi, C.; Buiarelli, F.; Gallo, V. Oxygenated polycyclic aromatic hydrocarbons in size-segregated urban aerosol. J. Aerosol Sci. 2015, 87, 126-134. [CrossRef]

30. Cecinato, A.; Mabilia, R.; Brachetti, A.; Di Filippo, P.; Liberti, A. Nitrated-PAH in urban air of Italy as indicators of motor vehicle emission and light-induced reactions. Anal. Lett. 2001, 34, 927-936. [CrossRef]

31. Borsella, E.; Di Filippo, P.; Riccardi, C.; Spicaglia, S.; Cecinato, A. Data quality of PAH determinations in environmental monitoring. Ann. Chim. 2004, 94, 691-698. [CrossRef]

32. Fromme, H.; Hilger, B.; Kopp, E.; Miserok, M.; Völkel, W. Polybrominated diphenyl ethers (PBDEs), hexabromocyclododecane (HBCD) and "novel" brominated flame retardants in house dust in Germany. Environ. Int. 2014, 64, 61-68. [CrossRef]

33. De la Torre, A.; Navarro, I.; Sanz, P.; Martínez, M.d.L.Á. Organophosphate compounds, polybrominated diphenyl ethers and novel brominated flame retardants in European indoor house dust: Use, evidence for replacements and assessment of human exposure. J. Hazard. Mater. 2020, 382, 121009. [CrossRef]

34. Iwegbue, C.M.A.; Eyengho, S.B.; Egobueze, F.E.; Odali, E.W.; Tesi, G.O.; Nwajei, G.E.; Martincigh, B.S. Science of the Total Environment Polybrominated diphenyl ethers and polychlorinated biphenyls in indoor dust from electronic repair workshops in southern Nigeria: Implications for onsite human exposure. Sci. Total Environ. 2019, 671, 914-927. [CrossRef]

35. Rudel, R.A.; Seryak, L.M.; Brody, J.G. PCB-containing wood floor finish is a likely source of elevated PCBs in residents' blood, household air and dust: A case study of exposure. Environ. Heal. A Glob. Access Sci. Source 2008, 7, 1-8. [CrossRef] [PubMed]

36. Wang, J.; Wang, Y.; Shi, Z.; Zhou, X.; Sun, Z. Science of the Total Environment Legacy and novel brominated flame retardants in indoor dust from Beijing, China: Occurrence, human exposure assessment and evidence for PBDEs replacement. Sci. Total Environ. 2018, 618, 48-59. [CrossRef] [PubMed]

37. Wemken, N.; Drage, D.S.; Abdallah, M.A.E.; Harrad, S.; Coggins, M.A. Concentrations of Brominated Flame Retardants in Indoor Air and Dust from Ireland Reveal Elevated Exposure to Decabromodiphenyl Ethane. Environ. Sci. Technol. 2019, 53, 9826-9836. [CrossRef] [PubMed]

38. Venier, M.; Vojta, Š.; Be, J.; Romanak, K.; Melymuk, L.; Krátká, M.; Kuku, P.; Okeme, J.; Saini, A.; Diamond, M.L.; et al. Brominated flame retardants in the indoor environment-Comparative study of indoor contamination from three countries. Environ. Int. 2016, 94, 150-160. [CrossRef] [PubMed]

39. Wang, W.; Abualnaja, K.O.; Asimakopoulos, A.G.; Covaci, A.; Gevao, B.; Johnson-restrepo, B.; Kumosani, T.A.; Malarvannan, G.; Binh, T.; Moon, H.; et al. A comparative assessment of human exposure to tetrabromobisphenol A and eight bisphenols including bisphenol A via indoor dust ingestion in twelve countries. Environ. Int. 2015, 83, 183-191. [CrossRef] [PubMed]

40. Sjo, A. Flame Retardants in Indoor Air at an Electronics Recycling Plant and at Other Work Environments. Environ. Sci. Technol. 2001, 35, 448-454.

41. Kajiwara, N.; Noma, Y.; Takigami, H. Brominated and organophosphate flame retardants in selected consumer products on the Japanese market in 2008. J. Hazard. Mater. 2011, 192, 1250-1259. [CrossRef]

42. Cequier, E.; Ionas, A.C.; Covaci, A.; Marce, R.M.; Becher, G.; Thomsen, C. Occurrence of a Broad Range of Legacy and Emerging Flame Retardants in Indoor Environments in Norway. Environ. Sci. Technol. 2014, 48, 6827-6835. [CrossRef]

43. Genisoglu, M.; Sofuoglu, A.; Kurt-karakus, P.B.; Birgul, A.; Sofuoglu, S.C. Chemosphere Brominated flame retardants in a computer technical service: Indoor air gas phase, submicron (PM 1) and coarse (PM 10) particles, associated inhalation exposure, and settled dust. Chemosphere 2019, 231, 216-224. [CrossRef]

44. Dodson, R.E.; Perovich, L.J.; Covaci, A.; Van Den Eede, N.; Ionas, A.C.; Dirtu, A.C.; Brody, J.G.; Rudel, R.A. After the PBDE phase-out: A broad suite of flame retardants in repeat house dust samples from California. Environ. Sci. Technol. 2012, 46, 13056-13066. [CrossRef] [PubMed] 
45. Tay, J.H.; Sellström, U.; Papadopoulou, E.; Padilla-Sánchez, J.A.; Haug, L.S.; de Wit, C.A. Assessment of dermal exposure to halogenated flame retardants: Comparison using direct measurements from hand wipes with an indirect estimation from settled dust concentrations. Environ. Int. 2018, 115, 285-294. [CrossRef] [PubMed]

46. US EPA (Environmental Protection Agency). Chapter 5: Soil and Dust Ingestion. In Exposure Factors Handbook; Update; EPA/600/R-17/384F; US EPA Office of Research and Development: Washington, DC, USA, 2017.

47. Jones-Otazo, H.A.; Clarke, J.P.; Diamond, M.L.; Archbold, J.A.; Ferguson, G.; Harner, T.; Richardson, G.M.; Ryan, J.J.; Wilford, B. Is house dust the missing exposure pathway for PBDEs? An analysis of the urban fate and human exposure to PBDEs. Environ. Sci. Technol. 2005, 39, 5121-5130. [CrossRef] [PubMed]

48. Roosens, L.; Cornelis, C.; D’Hollander, W.; Bervoets, L.; Reynders, H.; Van Campenhout, K.; Van Den Heuvel, R.; Neels, H.; Covaci, A. Exposure of the Flemish population to brominated flame retardants: Model and risk assessment. Environ. Int. 2010, 36, 368-376. [CrossRef] [PubMed]

49. Thomas, K.; Xue, J.; Williams, R.; Jones, P.; Whitaker, D. Polychlorinated Biphenyls (PCBs) in School Buildings: Sources, Environmental Levels, and Exposure; US EPA Office of Research and Development: Washington, DC, USA, 2012.

50. Pawar, G.; Abdallah, M.A.E.; De Sáa, E.V.; Harrad, S. Dermal bioaccessibility of flame retardants from indoor dust and the influence of topically applied cosmetics. J. Expo. Sci. Environ. Epidemiol. 2017, 27, 100-105. [CrossRef] [PubMed]

51. US EPA (Environmental Protection Agency). Exposure Factors Handbook: 2011 Edition; US EPA Office of Research and Development: Washington, DC, USA, 2011; ISBN EPA/600/R-090/052F.

52. Chen, M.; Jiang, J.; Gan, Z.; Yan, Y.; Ding, S.; Su, S.; Bao, X. Grain size distribution and exposure evaluation of organophosphorus and brominated flame retardants in indoor and outdoor dust and PM10 from Chengdu, China. J. Hazard. Mater. 2019, 365, 280-288. [CrossRef]

53. Knudsen, G.A.; Hughes, M.F.; Sanders, J.M.; Hall, S.M.; Birnbaum, L.S. Estimation of human percutaneous bioavailability for two novel brominated flame retardants, 2-ethylhexyl 2,3,4,5-tetrabromobenzoate (EH-TBB) and bis(2-ethylhexyl) tetrabromophthalate (BEH-TEBP). Toxicol. Appl. Pharmacol. 2016, 311, 117-127. [CrossRef]

54. Frederiksen, M.; Vorkamp, K.; Jensen, N.M.; Sørensen, J.A.; Knudsen, L.E.; Sørensen, L.S.; Webster, T.F.; Nielsen, J.B. Dermal uptake and percutaneous penetration of ten flame retardants in a human skin ex vivo model. Chemosphere 2016, 162, 308-314. [CrossRef]

55. Faroon, O.M.; Keith, S.L.; Smith-Simon, C.; De Rosa, C.T. Polychlorinated biphenyls-human health aspects. Int. Multidiscip. Sci. GeoConference Surv. Geol. Min. Ecol. Manag. SGEM 2015, 1, 647-654.

56. US EPA (Environmental Protection Agency). US EPA's Integrated Risk Information System (IRIS) Database. 2008. Available online: http://www.epa.gov/ncea/iris/subst/ (accessed on 1 March 2020).

57. US EPA (Environmental Protection Agency). Provisional Peer-Reviewed Toxicity Values 2,4,6-Tribromophenol (CASRN 118-79-6); EPA/690/R-09/063F; US EPA Office of Research and Development: Washington, DC, USA, 2012.

58. Niu, D.; Qiu, Y.; Du, X.; Li, L.; Zhou, Y.; Yin, D.; Lin, Z.; Chen, L.; Zhu, Z.; Zhao, J.; et al. Novel brominated flame retardants in house dust from Shanghai, China: Levels, temporal variation, and human exposure. Environ. Sci. Eur. 2019, 31. [CrossRef]

59. Ruan, Y.; Zhang, X.; Qiu, J.W.; Leung, K.M.Y.; Lam, J.C.W.; Lam, P.K.S. Stereoisomer-Specific Trophodynamics of the Chiral Brominated Flame Retardants HBCD and TBECH in a Marine Food Web, with Implications for Human Exposure. Environ. Sci. Technol. 2018, 52, 8183-8193. [CrossRef] [PubMed]

60. Ali, N.; Ali, L.; Mehdi, T.; Dirtu, A.C.; Al-Shammari, F.; Neels, H.; Covaci, A. Levels and profiles of organochlorines and flame retardants in car and house dust from Kuwait and Pakistan: Implication for human exposure via dust ingestion. Environ. Int. 2013, 55, 62-70. [CrossRef] [PubMed]

61. Wikoff, D.; Thompson, C.; Perry, C.; White, M.; Borghoff, S.; Fitzgerald, L.; Haws, L.C. Development of toxicity values and exposure estimates for tetrabromobisphenol A: Application in a margin of exposure assessment. J. Appl. Toxicol. 2015, 35, 1292-1308. [CrossRef] [PubMed]

(C) 2020 by the authors. Licensee MDPI, Basel, Switzerland. This article is an open access article distributed under the terms and conditions of the Creative Commons Attribution (CC BY) license (http://creativecommons.org/licenses/by/4.0/). 